Prepared for the U.S. Department of Energy

under Contract DE-AC05-76RL01830

\title{
Supply Security in Future Nuclear Fuel Markets
}

AM Seward

TW Wood

ET Gitau

BE Ford

November 2013

Pacific Northwest

NATIONAL LABORATORY

Proudly Operated by Battelle Since 1965 


\title{
DISCLAIMER
}

This report was prepared as an account of work sponsored by an agency of the United States Government. Neither the United States Government nor any agency thereof, nor Battelle Memorial Institute, nor any of their employees, makes any warranty, express or implied, or assumes any legal liability or responsibility for the accuracy, completeness, or usefulness of any information, apparatus, product, or process disclosed, or represents that its use would not infringe privately owned rights. Reference herein to any specific commercial product, process, or service by trade name, trademark, manufacturer, or otherwise does not necessarily constitute or imply its endorsement, recommendation, or favoring by the United States Government or any agency thereof, or Battelle Memorial Institute. The views and opinions of authors expressed herein do not necessarily state or reflect those of the United States Government or any agency thereof.

\author{
PACIFIC NORTHWEST NATIONAL LABORATORY \\ operated by \\ BATTELLE \\ for the \\ UNITED STATES DEPARTMENT OF ENERGY \\ under Contract DE-AC05-76RL01830
}

Printed in the United States of America
Available to DOE and DOE contractors from the Office of Scientific and Technical Information,
P.O. Box 62, Oak Ridge, TN 37831-0062;
ph: (865) 576-8401
fax: $(865)$ 576-5728
email: reports@adonis.osti.gov

\begin{abstract}
Available to the public from the National Technical Information Service, U.S. Department of Commerce, 5285 Port Royal Rd., Springfield, VA 22161 ph: (800) 553-6847 fax: $(703) 605-6900$ email: orders@ntis.fedworld.gov online ordering: http://www.ntis.gov/ordering.htm
\end{abstract}

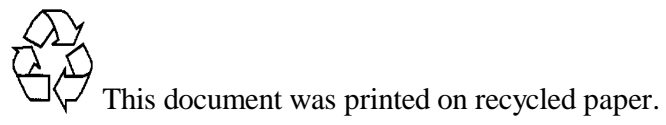




\title{
Supply Security in Future Nuclear Fuel Markets
}

\author{
AM Seward TW Wood \\ ET Gitau BE Ford
}

November 2013

Prepared for

the U.S. Department of Energy

under Contract DE-AC05-76RL01830

Pacific Northwest National Laboratory

Richland, Washington 99352 



\begin{abstract}
Previous PNNL work has shown the existing nuclear fuel markets to provide a high degree of supply security, including the ability to respond to supply disruptions that occur for technical and non-technical reasons. ${ }^{1}$ It is in the context of new reactor designs - that is, reactors likely to be licensed and market ready over the next several decades - that fuel supply security is most relevant. Whereas the fuel design and fabrication technology for existing reactors are well known, the construction of a new set of reactors could stress the ability of the existing market to provide adequate supply redundancy. This study shows this is unlikely to occur for at least thirty years, as most reactors likely to be built in the next three decades will be evolutions of current designs, with similar fuel designs to existing reactors.
\end{abstract}

\footnotetext{
${ }^{1}$ See: AM Seward, TW Wood, CM Toomey et al. Redundancy of Supply in the International Nuclear Fuel Fabrication Market: Are Fabrication Services Assured? PNNL-20861. October 2011.

CM Toomey, AM Seward, TW Wood et al. Redundancy of Supply in the International Nuclear Fuel Market: Technically Redundant and Politically Assured Fuel Supply. INMM. PNNL-85476. July 2012.

TW Wood, AM Seward. Redundancy of Fuel Fabrication Services in the International Nuclear Fuel Market. PNNL-19234. February 2010.
} 



\section{Acronyms and Abbreviations}

ACR

AGR

APR

ARIS

BWR

DOE

EPR

GE-H

Gen II

Gen II

Gen III+

Gen IV

GNF

IAEA

LEU

LWR

MSR

MTU/yr

NNSA

NSSS

PHWR

PNNL

PWR

RBMK

SCWR

SMR

VHTR

VVER advanced CANDU reactor

advanced gas reactor

advanced power reactor

Advanced Reactors Information System

boiling water reactor

U.S. Department of Energy

European pressurized reactor

General Electric-Hitachi

Generation II (reactor)

Generation III (reactor)

Generation III+ (reactor)

Generation IV (reactor)

Global Nuclear Fuel

International Atomic Energy Agency

low-enriched uranium

light water reactor

molten salt reactor

metric tons/year

National Nuclear Security Administration

Nuclear Steam Supply System

pressurized heavy water reactor

Pacific Northwest National Laboratory

pressurized water reactor

Reaktor Bolschoi Moshchnosty Kanani

supercritical water-cooled reactor

small- and medium-sized reactors

very high temperature reactor

Vodo-Vodyanoi Energetichesky Reactor 



\section{Contents}

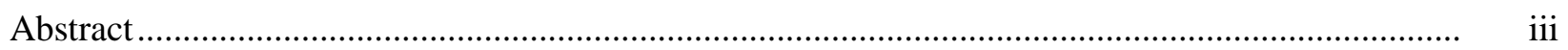

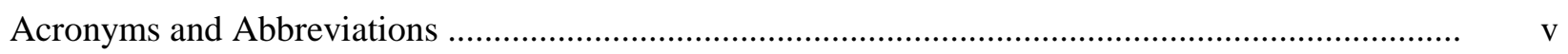

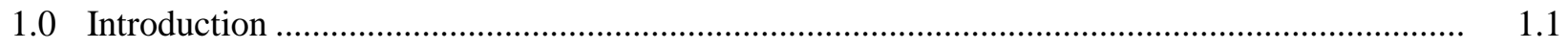

1.1 Nuclear Reactors: Technology and Evolution.............................................................. 1.1

1.2 Nuclear Reactor: Fuel Technology and Evolution of Fuel Design ................................. 1.4

1.3 Nuclear Fuel: Market Structure and Evolution ............................................................. 1.6

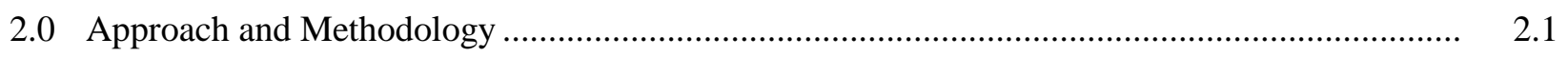

2.1 Survey of Potentially Available Technologies ............................................................. 2.1

2.2 Country Selection: Demand Side ............................................................................. 2.2

2.3 Aligning Supply and Demand According to Nuclear Capacity Growth Forecast............... $\quad 2.3$

2.4 Net Generation, Retirements, and New Builds ............................................................ 2.3

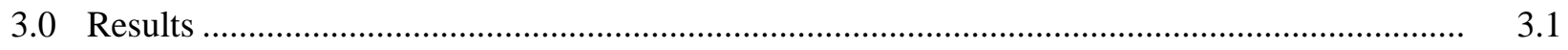

3.1 Results of Expert Elicitation to Define Population of Anticipated Reactors ..................... 3.1

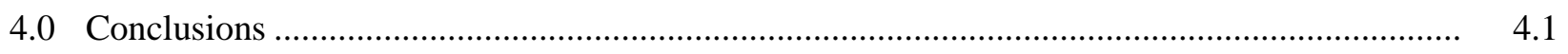

Appendix - PNNL Nuclear Fuel Fabrication Market Model........................................................... A.1

\section{Figures}

1.1 Evolution of Nuclear Reactor Technology ..................................................................... 1.3

1.2 Nuclear Reactor Market Consolidation ….......................................................................... 1.7

\section{Tables}

1.1 Nuclear Power Reactor Population by Type .................................................................... 1.2

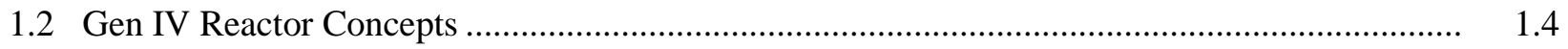

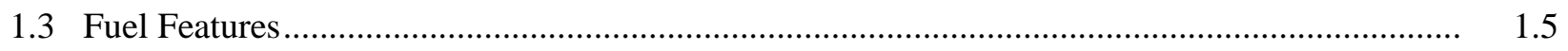

1.4 International Nuclear Fuel Fabrication Market................................................................. 1.7

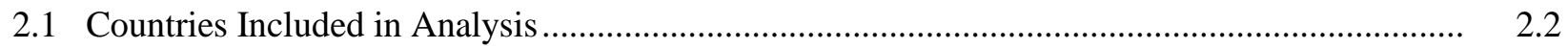

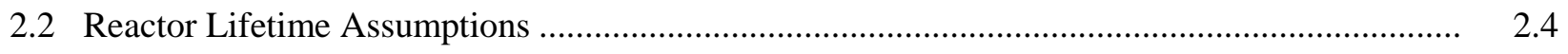

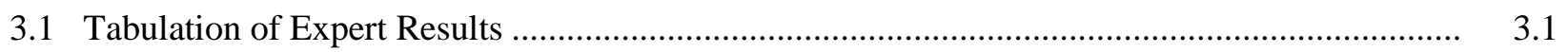





\subsection{Introduction}

Pacific Northwest National Laboratory (PNNL) has for several years been assessing the reliability of nuclear fuel supply in support of the U.S. Department of Energy/National Nuclear Security Administration. Previous PNNL work has addressed the ability of the existing market to respond to supply disruptions that could occur for technical and non-technical reasons. ${ }^{1}$ This previous analysis determined that existing fabrication plants could provide backup fabrication services to most of the world's power reactors, assuming that alternative fabricators were willing to provide backup services and able to obtain the necessary regulatory certifications.

This study is an assessment of the reactor technology and fuel requirements of reactors anticipated to be licensed through 2050. It is in the context of anticipated reactors - that is, reactors defined in this study as those likely to be licensed and market ready between now and 2050 - that fuel supply security is most relevant. Whereas the fuel requirements of existing reactors are well known, the construction of a new fleet of reactors could strain the existing market's capacity to provide adequate supply redundancy. Of specific interest in this study is whether reactor designs emerging during this time period would require new fuel manufacturing technology, which could prove a "disruptive innovation" in the fuel markets.

\subsection{Nuclear Reactors: Technology and Evolution}

There are currently some 440 commercially operating nuclear power reactors globally, with another 30 reactors under construction or scheduled to be restarted. Table 1.1 presents a breakdown of reactor types and market share of all commercial reactors in the world. The majority of these are light water reactors (LWR), with pressurized water reactors (PWR) (including vodo-vodyanoi energetichesky reactors [VVER]) accounting for some 66 percent of all power reactors. Pressurized heavy water reactors (PHWR) were developed for commercial use by Canada and successfully exported to a number of countries, including Argentina, China, South Korea, and Romania. BWRs are the second most common

\footnotetext{
${ }^{1}$ PNNL analysis characterized the functioning and efficacy of the fuel fabrication market in circumstances in which the primary supply is disrupted at the technical (i.e., fabrication plant) and non-technical (i.e., country) levels. PNNL developed a data-based model (relying on NAC International's FuelTrac) of the fuel fabrication market to simulate fabrication plant outages. The model simulated outages of varying durations at specific fabrication plants and output predictions about the reactors affected and the degree of fuel delivery delay. By applying a set of constrained assumptions about a fabricators' technical ability to build specific fuel designs, the modeling provided some initial insight into the extent of vulnerability to nuclear fuel supply disruption at the level of individual fabrication plants, reactors, and countries. See: 1) AM Seward, TW Wood, CM Toomey et al., Redundancy of Supply in the International Nuclear Fuel Fabrication Market: Are Fabrication Services Assured? PNNL. October 2011; 2) CM Toomey, AM Seward, TW Wood et al. Redundancy of Supply in the International Nuclear Fuel Market: Technically Redundant and Politically Assured Fuel Supply. INMM. July 2012; 3) TW Wood, AM Seward. Redundancy of Fuel Fabrication Services in the International Nuclear Fuel Market. PNNL 19234. February 2010.
} 
type of reactor. Reaktor bolschoi moshchnosty kanani (RBMK) ${ }^{1}$ reactors are operational only in Russia, and operating advanced gas-cooled reactors (AGRs) and Magnox reactors ${ }^{2}$ are limited to the United Kingdom.

Table 1.1. Nuclear Power Reactor Population by Type

\begin{tabular}{lc}
\hline \multicolumn{1}{c}{ Reactor Type } & Percent of Population \\
\hline PWR $^{(a)}$ & 65.6 \\
BWR & 22.9 \\
PHWRs & 6.0 \\
RBMK & 3.1 \\
Gas-Cooled Reactors (Magnox, AGR) & 2.4 \\
\hline (a) Includes VVERs. & \\
Source: NEA/OECD 2009 & \\
\hline
\end{tabular}

Power reactor designs have evolved, and are continuing to evolve, thorough several generations. Figure 1.1 presents a timeline for each generation and several examples of specific designs of each. The current operating global nuclear fleet is primarily composed of Generation II (Gen II) reactor designs. These facilities were designed to operate for 40 years and rely upon " ... active safety features involving electrical and mechanical operations that are initiated automatically" or by an operator. China, Russia, and South Korea have recently begun operations at several Gen II reactor facilities. China is currently the only country with plans to continue building Gen II reactors. After the accident at Fukushima in 2011, the Chinese State Council Research Office released a report containing its independent policy recommendations for strategic nuclear development. The State Council Research Organization stated in the report that the number of Gen II reactors under construction should not be large given international concerns over their safety. ${ }^{3}$ As a result, China has worked to increase safety at its Gen II facilities to Generation III (Gen III) standards and modified its plans to focus on the adoption of Gen III reactors.

\footnotetext{
${ }^{1}$ RBMK also is as the High-Power Channel-Type Reactor. The RBMK is a Russian PWR distinguished by individual fuel channels and the use of graphite as a moderator.

${ }^{2}$ Magnox reactors are graphite-moderated, gas-cooled reactors that use natural uranium for fuel and magnesium alloy as the fuel cladding. The Magnox design was replaced by the advanced gas-cooled reactor (AGR) design, and only one Magnox reactor remains in operation, with shutdown expected in the near future. There are currently14 AGRs in operation on some seven sites. Both reactor designs are obsolete; no more reactors of either design are planned for construction.

${ }^{3} \mathrm{http}: / /$ www.world-nuclear-news.org/NP_Maintain_nuclear_perspective_China_told_1101112.html
} 


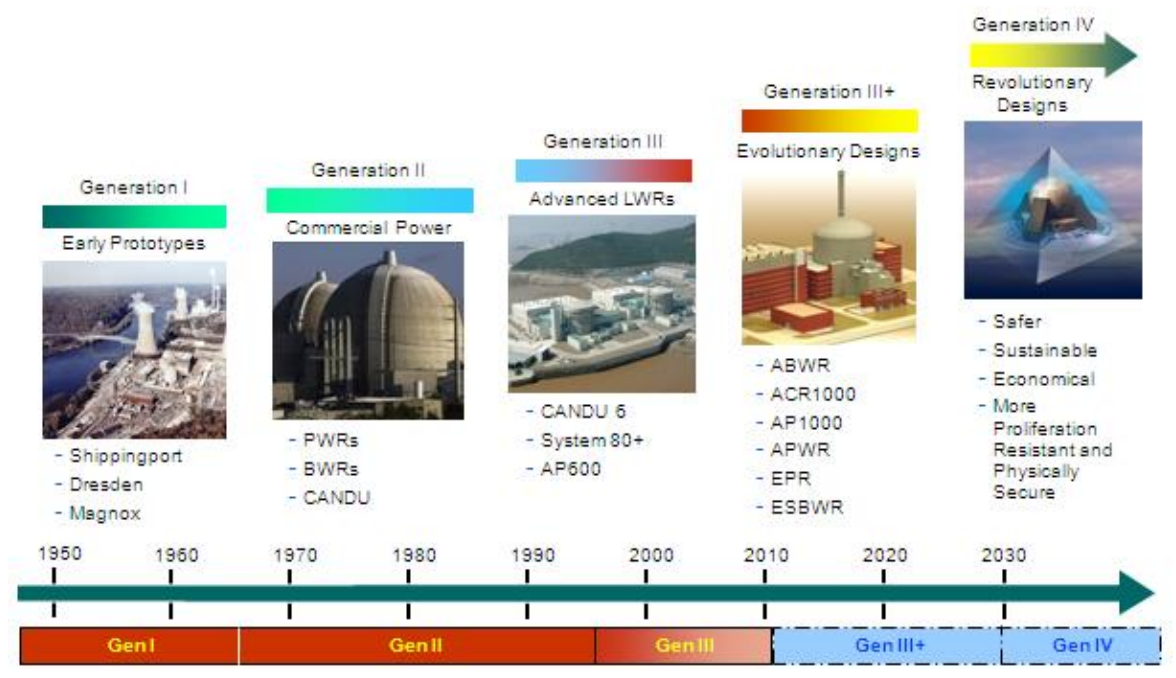

Figure 1.1. Evolution of Nuclear Reactor Technology ${ }^{1}$

The majority of reactors currently under construction for commercial operation are Gen III reactors. While there is no universally accepted technical distinction between Generation II (Gen II) and Gen III reactors, Gen III reactors can be characterized by evolutionary improvements in safety, reliability, and efficiency. Designs widely considered to fall under this category include the CANDU 6 and AP600. An extension of this category is known as Generation III+ (Gen III+). Gen III+ reactors offer significant improvement in safety with systems incorporating passive features that do not require active controls or operator intervention during off-normal or accident scenarios. ${ }^{2}$ Designs that fall into this category include the European Pressurized Reactor (EPR), Advanced CANDU Reactor (ACR)-1000, and Advanced Power Reactor (APR)-1400.

In the near term, Gen III/III+ designs will continue to be developed and deployed. However, in the coming decades more advanced reactor designs known as Generation IV (Gen IV) reactors and small- and medium-sized reactors (SMRs) will enter, and may ultimately dominate, the reactor market.

Gen IV reactor designs have been under development for decades, with several demonstration and prototype facilities being successfully operated. However, it was not until 2001 when the Gen IV International Forum (GIF) ${ }^{3}$ was established to coordinate global research and development efforts. In late 2002, GIF announced that it had identified six reactor concepts as priorities for deployment between 2020 and 2030. These Gen IV concepts, which are presented in Table 1.2, are expected to offer increased safety, higher efficiency, cogeneration opportunities, reduced wastes, and increased proliferation resistance and security.

\footnotetext{
${ }^{1}$ http://www.gen-4.org/Technology/evolution.htm.

${ }^{2}$ Goldberg, SM and R Rosner, Nuclear Reactors: Generation to Generation. American Academy of Arts and Sciences, 2011.

${ }^{3}$ Members as of September 2013: Canada, China, Euratom, France, Japan, South Korea, Russia, South Africa, Switzerland, United States, Argentina, Brazil, United Kingdom
} 
Table 1.2. Gen IV Reactor Concepts ${ }^{1}$

\begin{tabular}{ll}
\hline \multicolumn{1}{c}{ Reactor Concept } & \multicolumn{1}{c}{ Description } \\
\hline $\begin{array}{l}\text { Gas-cooled fast reactor } \\
\text { Very high temperature } \\
\text { reactor (VHTR) }\end{array}$ & $\begin{array}{l}\text { Fast neutron spectrum, helium cooled, and closed fuel cycle } \\
\text { Graphite-moderated, helium-cooled reactor with a once-through uranium fuel cycle }\end{array}$ \\
$\begin{array}{l}\text { Supercritical water-cooled } \\
\text { reactor (SCWR) }\end{array}$ & $\begin{array}{l}\text { High-temperature, high-pressure, water-cooled reactor that operates above the } \\
\text { thermodynamic critical point of water }\end{array}$ \\
$\begin{array}{l}\text { Sodium-cooled fast } \\
\text { Leactor }\end{array}$ & Fast neutron spectrum, sodium-cooled reactor, and closed fuel cycle \\
Molten salt reactor (MSR) & $\begin{array}{l}\text { Fast neutron spectrum, lead/bismuth-cooled reactor, and closed fuel cycle } \\
\text { Produces fission power in a circulating molten salt mixture with an epithermal- } \\
\text { spectrum reactor and a full actinide recycling center }\end{array}$ \\
\hline
\end{tabular}

With the growing global nuclear renaissance, an interest in SMRs from smaller countries with limited grid capabilities has pushed new research and development into these types of reactor designs. SMRs are expected to offer better safety, security, and proliferation resistance. These designs also are expected to provide new nuclear countries with unstable or small grids a scalable nuclear option and allow the countries to increase capacity at a lower, and less expensive, rate than traditional large-scale reactors. SMRs are defined as reactors that produce less than 700 MWe from either a single unit or collection of smaller units. As part of this definition, small-sized reactors are produce less than $300 \mathrm{MWe}$, while medium-sized reactors produce between 300 MWe and 700 MWe. Numerous SMR designs have been released; however, the International Atomic Energy Agency (IAEA) has captured only 32 designs as part of its Advanced Reactors Information System (ARIS) database. These SMR designs can be placed into two categories: LWR designs and non-LWR designs. LWR designs incorporate system elements traditionally found in large, commercial PWRs and BWRs, while the non-LWR SMR designs are similar to larger liquid metal-cooled reactors, heavy-water reactors, and gas-cooled reactors. Many of the nonLWR SMR designs also represent smaller-scale Gen IV reactor concepts.

\subsection{Nuclear Reactor: Fuel Technology and Evolution of Fuel Design}

Over the past 40 years, fuel design has continuously evolved, with improvements including the use of advanced alloys, incorporation of debris screens, use of burnable poisons, and evolution of array geometry. This has resulted in better fuel performance - including lower fuel failure rates and increased burnup).

Designing a new type of fuel and fabricating a fuel element or assembly, and then qualifying it for use in a reactor, is a lengthy and costly engineering development program that must satisfy many regulatory requirements. $^{2}$ It typically takes some 15 years from the time a fuel design improvement is identified and the time when full fuel cores incorporating the innovation are deployed in a reactor. ${ }^{3}$

\footnotetext{
${ }^{1}$ Source: Based on information presented on Generation IV International Forum website. http://www.gen4.org/Technology/systems/index.htm

${ }^{2}$ http://energy.gov/ne/advanced-modeling-simulation/nuclear-fuels

${ }^{3}$ This information is based on Framatome ANP experience. Michel Watteau, Bernard Estève et al. Framatome ANP Extended Burnup Experience and Views on LWR Fuels. World Nuclear Association. 2001.
} 
Reactor fuel is tailored to the specific needs of an individual reactor, which are determined by the physical characteristics of the reactor, the operating utility's fuel cycle management strategy, and national (or in some cases regional) licensing requirements. ${ }^{1}$ Hence, fabricated fuel, in general, is usable only in a reactor of a specific design, and in many cases, only in an individual reactor. Table 1.3 describes the features of various fuel types for commercial nuclear power reactors currently in operation globally.

Table 1.3. Fuel Features ${ }^{2}$

\begin{tabular}{|c|c|c|c|c|}
\hline Reactor Type & Fuel Material & $\begin{array}{l}\text { Fuel Pin } \\
\text { Cladding }\end{array}$ & Typical Assembly & Enrichment \\
\hline AGR & $\overline{\mathrm{UO}_{2}}$ & Stainless Steel & $\begin{array}{l}\text { Circular array of pins in graphite } \\
\text { sleeve }\end{array}$ & $2-4 \%$ \\
\hline Magnox & U metal & Magnesium alloy & Circular rod & Natural \\
\hline PHWR & $\mathrm{UO}_{2}$ & Zirconium alloy & Circular bundle & Natural \\
\hline RBMK & $\mathrm{UO}_{2}$ & Zirconium alloy & Circular array & Up to $2.8 \%$ \\
\hline BWR & $\mathrm{UO}_{2}$ & Zirconium alloy & Square array & Up to $4.95 \%$ \\
\hline PWR & $\mathrm{UO}_{2}$ & Zirconium alloy & Square array & Up to $4.95 \%$ \\
\hline VVER & $\mathrm{UO}_{2}$ & Zirconium alloy & Hexagonal array & Up to $4.95 \%$ \\
\hline
\end{tabular}

Gen IV and SMR reactor designs are expected to use a range of fuel designs and materials, with many relying upon current, or slightly evolved, low enriched uranium (LEU) fuel designs. Except for the VHTR and MSR, Gen IV reactor designs are expected to be capable of using entire core loads of pin-type MOX fuel that contains uranium, thorium, plutonium, and/or minor actinides to be burned in order to reduce wastes. Designs for the lead-cooled fast reactor and the gas-cooled fast reactor have been developed that are capable of using uranium nitride fuel. The VHTR and MSR present the most radical change in fuel design for Gen IV reactors. The VHTR uses TRISO-coated particle uranium, plutonium, and/or thorium fuel in either a pebble or prismatic form to create the fuel assembly. The MSR has two design derivatives, one that uses a liquid fluoride salt containing uranium or thorium as a fuel. The other uses prismatic fuel elements containing TRISO-coated fuel particles that are cooled using a molten salt. Among SMRs, medium-sized LWR SMR designs plan to utilize current standard LWR fuel assemblies. Many small-sized LWR SMR designs plan to use assemblies similar to standard LWR assemblies, but that are only half the height of those found in large-scale commercial reactor facilities. Fuel designs among non-LWR SMR designs will vary with each design. SMR variants of Gen IV designs can be expected to utilize fuel types similar to their larger Gen IV cousins.

A few preliminary conclusions can be drawn on the likely evolution of fuel design:

\footnotetext{
${ }^{1}$ http://world-nuclear.org/info/Nuclear-Fuel-Cycle/Conversion-Enrichment-and-Fabrication/Fuel-Fabrication/

2 "Current Trends in Nuclear Fuel for Power Reactors." IAEA Information Document for IAEA General

Conference. September 2007. http://www.iaea.org/About/Policy/GC/GC51/GC51InfDocuments/English/gc51inf-3att5_en.pdf
} 
[1] Existing fuel design has evolved to extract increasing performance from a basic design. Further evolution will [a] yield increasingly small performance changes at the margin, but [b] ensure that fuel can be made pretty much as it is now

[2] At some point, the prospect of large performance increases will justify jumping to a radically new core and fuel design. This will be disruptive innovation for the fuel manufacture industry.

[3] Gen III and III+ designs will not produce the type of fuel manufacture revolution described in [2], but some Gen IV designs (including SMR variant of these), will. Thus the timing for radical change in fuel fab market is dictated by the timing (and pace of introduction) of these specific designs.

\subsection{Nuclear Fuel: Market Structure and Evolution}

There are currently three major global suppliers of LWR fuel: the French-owned company AREVA, Westinghouse (owned by Toshiba), and Global Nuclear Fuels (GNF), which is a joint venture of General Electric, Toshiba, and Hitachi (General Electric, 51 percent; Toshiba, 24.5 percent; Hitachi, 24.5 percent). Typically, the reactor vendor supplies the first core and the initial reloads. Thereafter, LWR fuel is purchased in a set of a competitive markets in which fabricators compete to supply fuel for some reactors of their competitors' designs. Most of this competition is based on product differentiation (comparative fuel performance) rather than price. Table 1.4 presents respective vendor shares of the fuel market.

Smaller national and regional fuel fabricators serve local markets in Argentina, Brazil, China, Canada, India, Japan, Romania, South Korea, ${ }^{1}$ and Spain. These include non-LWR fabricators (i.e., PHWRs). Most of the smaller vendors entered the market later than the largest fuel and reactor vendors, and they largely service indigenous reactors, although they also may have licensing arrangements to supply fuel to reactors designed by foreign vendors. Key players among these smaller fuel fabricators are ENUSA (Spain), China National Nuclear Corporation, and Korea Nuclear Fuel Company Ltd. (KNFC South Korea). Such vendors tend to be dominant (and sometimes exclusive) suppliers for their domestic fuel markets.

PHWR fuel warrants special note in this regard, as it is produced almost exclusively by the countries in which these reactors are located. Because PHWRs use natural or slightly enriched uranium in large quantities, fuel fabrication facilities are typically part of the initial reactor deal. However, on occasion, PHWR fuel may be imported from a foreign supplier. ${ }^{2}$ Also of note is the market for MOX fuel. Currently, France, Japan, and India are the only countries that actively use MOX fuel as a part of operations for commercial reactor facilities. France and India are the only countries with domestic fabrication capacity to supply commercial fuel, while Japan is expected to begin fabrication operations in 2015 at its Rokkasho-Mura facility.

\footnotetext{
${ }^{1}$ South Korean fuel fabricator KNFC currently supplies fuel domestically. However, in July 2012, South Korea was awarded the fuel contract for the four reactors being built at the Barakah site in the UAE. This contract is expected to cover the first 15 years of operation for the 4 units. [http://www.enec.gov.ae/media-centre/news/content/emiratesnuclear-energy-corporation]

${ }^{2}$ World Nuclear Association 2007. Advanced CANDU reactors (ACRs) use slightly enriched uranium.
} 
Table 1.4. International Nuclear Fuel Fabrication Market $^{1}$

\begin{tabular}{lc}
\hline \multicolumn{1}{c}{ Vendor } & Market Share (\%) \\
\hline AREVA & 31.7 \\
Westinghouse-Toshiba & 20.3 \\
Global Nuclear Fuel (GNF) & 19.0 \\
TVEL (Atomenergoprom) & 7.8 \\
Nuclear Fuel Industries & 5.2 \\
Mitsubishi Nuclear Fuel (MNF) & 4.3 \\
Enusa & 3.9 \\
Korea Nuclear Fuel Company (KNFC) & 3.9 \\
China National Nuclear Fuel Corp (CNNC) & 2.0 \\
Industrias Nucleares do Brazil (INB) & 2.0 \\
\hline
\end{tabular}

As shown in Figure 1.2, there has been a marked consolidation of the reactor and fuel vendors over the past few decades. ${ }^{2}$

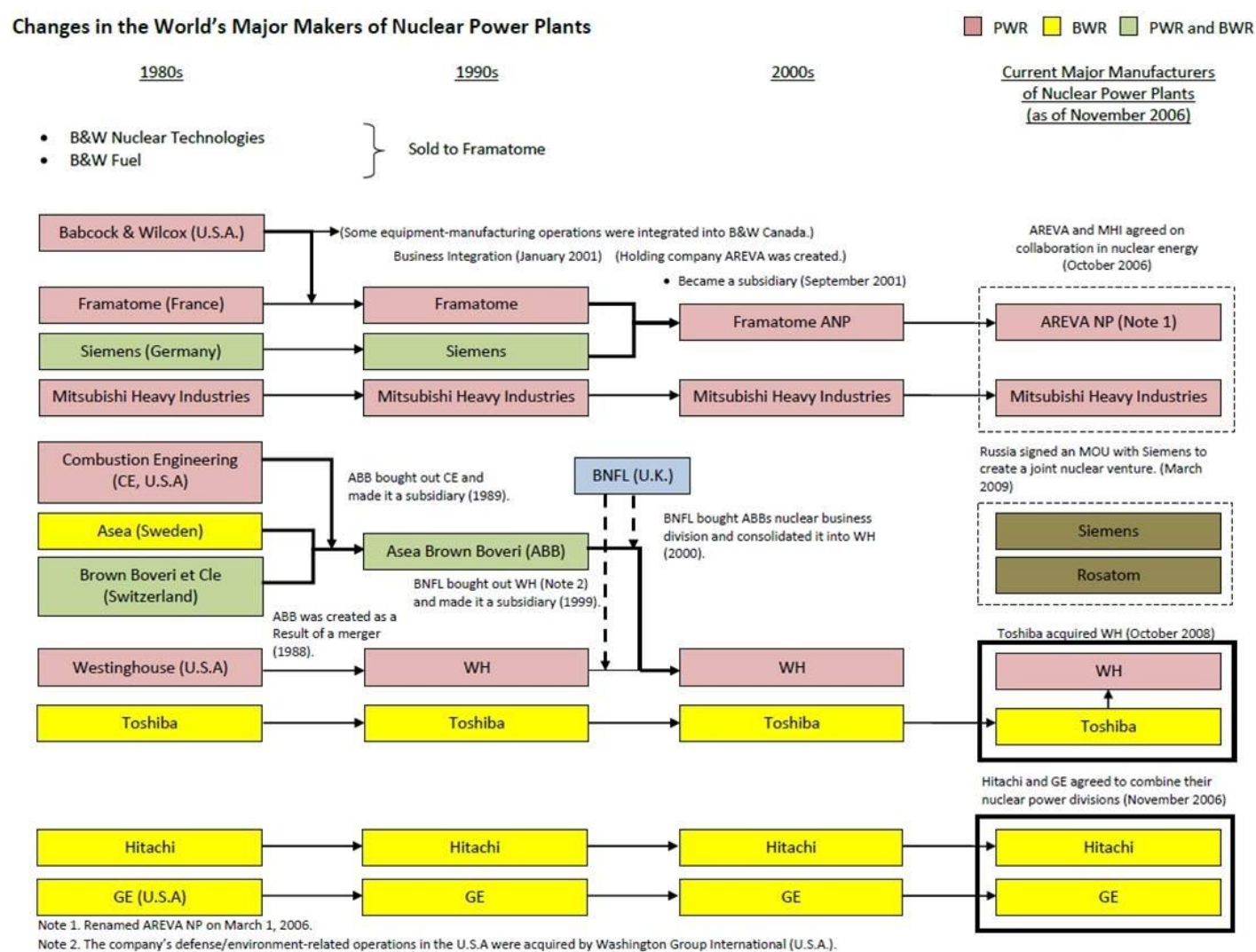

Figure 1.2. Nuclear Reactor Market Consolidation (METI, updated)

${ }^{1}$ Source: Market Competition in the Nuclear Industry. OECD 2007.

${ }^{2}$ Fifteen years ago, there were five major fabricators of LWR fuel: 1) Framatome-Cogema, 2) General Electric,

3) Westinghouse, 4) Siemens, and 5) Asea Brown Bovery-Combustion Engineering (NEA/OECD 2009). 
As with the reactor vendor market, there are technical, financial, and economic barriers to entry ${ }^{1}$ in the nuclear fuel fabrication market. Access to the technology (e.g., patents, processes, intellectual property) required to build a technically competitive product is the primary technical barrier.

Economic barriers also include the mutual fixed costs and investment required to commence a fuel fabrication plant. One measure of the economic barrier to entry is the "minimum economic scale." The minimum economic scale can be used to compare the cost of doing business for an economically feasible new entrant to an industry with the cost for an established firm. Rothwell calculated these figures for the LWR fuel fabrication market using a detailed cost model. ${ }^{2}$ The results showed that a new entrant must operate at a scale of about $1000 \mathrm{MTU}$ (metric tons uranium)/year to offer a competitive price. In contrast, an incumbent firm can operate at a minimum economic scale of $270 \mathrm{MTU} / \mathrm{year}$. Given that $1000 \mathrm{MTU}$ represents about 10 percent of the annual global fuel requirement, this presents a significant barrier to entry by new fabricators. ${ }^{3}$

Because the cost of fuel testing and innovation is borne by the fuel vendor, further advancement in fuel design will likely lead to greater industry concentration. Established firms with substantial R\&D capabilities are likely to be more competitive, and the barriers to entry by smaller, regional fuel fabricators will be greater.

The large investment of time and money required to develop competitive fuel designs also creates an economic threshold market size (number of reactors) below which it is not profitable to compete for fuel business. As a consequence, fuel designers tend to specialize in reactor types with at least four to five deployed units. This market paradigm makes supplying fuel for new and unproven reactors designs risky relative to their existing core business.

There is sufficient technical redundancy in the market for LWR fuel. ${ }^{4}$ The "international nuclear fuel market is clearly somewhat imperfect, but it has always performed well on its basic function of supplying reactors." Despite the potential for transportation delays, political supply disruptions, fabrication plant outages, and a myriad of other factors, the existing market has functioned well to supply nuclear fuel to operate power reactors.

\footnotetext{
${ }^{1}$ Freedom of entry is a prerequisite for perfect competition. To the extent that entry is restricted, (a few) existing firms may raise prices. The trend toward consolidation in the fabrication sector in the last two decades may impact competition within the industry.

${ }^{2}$ Rothwell G. Cost Structure and Market Sustainability of the International Light Water Reactor Fuel Fabrication Industry. April 2008.

${ }^{3}$ Ibid.

${ }^{4}$ See Wood T and A Seward. Redundancy of Fuel Fabrication Services in the International Nuclear Fuel Market. February 2010. PNNL-19234.

${ }^{5}$ Kidd S. "Fuel - nuclear power's trump card?” NEI Magazine. 7 July 2009.
} 


\subsection{Approach and Methodology}

Our analysis sought to align nuclear power technologies with anticipated nuclear capacity growth in countries where the greatest expansion is expected to occur. This required definition of supply (i.e., a set of anticipated reactors) and demand (i.e., the set of countries in which nuclear growth is projected to occur). It also required application of country-specific information about what types of reactors are likely to be of interest to individual countries. A set of nuclear growth forecasts was then used to align specific reactor types with individual countries through the period of analysis (through 2050).

\subsection{Survey of Potentially Available Reactor Designs}

This study relied upon the IAEA ARIS database ${ }^{1}$ to define the set of reactor designs under development from which designs with a reasonable chance of significant market penetration would be selected. The reactor set supplied by ARIS was supplemented with additional reactor designs not contained in the ARIS database to produce a comprehensive list of candidate designs for licensing and construction through the period of analysis (2012 to 2050). A separate analysis assessed the potential market penetration of competing SMR designs. The most prominent SMR designs, however, were included in the base study to account for this important reactor market.

Some 45 designs were chosen for evaluation. Information about the chosen designs is provided in Appendix A. This set of reactor designs was then evaluated by a group of PNNL reactor experts to determine which designs were potentially licensable. Each design was assessed based on the following nine objective criteria:

1. Nuclear steam and supply system (NSSS) vendor in place

2. Architect engineer in place

3. Site selected

4. At least one interested utility

5. Fuel supplier identified

6. Reactor design has licensing precedent

7. Funding source in place

8. Fuel material identified

9. Cladding material identified

A design needed to meet six of the nine criteria to be considered licensable and deployable in significant numbers in our study timeframe. After narrowing down likely candidate designs in this way, country-specific information was used to predict which reactor type (and how many) of each would be built.

\footnotetext{
${ }^{1}$ http://aris.iaea.org.
} 


\subsection{Country Selection - Demand Side}

According to the IAEA, some 30 states that do not currently have nuclear power are currently planning or considering its development. ${ }^{1}$ Given that fuel markets will be driven largely by growth in countries with large nuclear power programs, country selection for our study was limited to states in which $95 \%$ of new nuclear energy growth is projected to occur. ${ }^{2}$ The countries included in this study and their expected contributions to new global nuclear generating capacity are listed in Error! Not a valid bookmark self-reference..

Table 2.1. Countries Included in Analysis $^{3}$

\begin{tabular}{|c|c|c|}
\hline Country & $\begin{array}{l}\text { Projected Number of } \\
\text { Reactor Units }\end{array}$ & $\begin{array}{l}\text { Percentage of Projected Global } \\
\text { Nuclear Capacity Growth }\end{array}$ \\
\hline Belarus & 2 & $1 \%$ \\
\hline Brazil & 6 & $2 \%$ \\
\hline Bulgaria & 4 & $1 \%$ \\
\hline Canada & 5 & $2 \%$ \\
\hline China & 125 & $37 \%$ \\
\hline Czech Republic & 2 & $1 \%$ \\
\hline Egypt & 2 & $1 \%$ \\
\hline Finland & 5 & $1 \%$ \\
\hline France & 13 & $4 \%$ \\
\hline Hungary & 3 & $1 \%$ \\
\hline India & 32 & $10 \%$ \\
\hline Italy & 3 & $1 \%$ \\
\hline Japan & 9 & $3 \%$ \\
\hline Mexico & 3 & $1 \%$ \\
\hline Poland & 3 & $1 \%$ \\
\hline Russia & 19 & $6 \%$ \\
\hline South Africa & 5 & $1 \%$ \\
\hline South Korea & 21 & $6 \%$ \\
\hline Spain & 2 & $1 \%$ \\
\hline Taiwan & 5 & $2 \%$ \\
\hline Thailand & 2 & $1 \%$ \\
\hline Turkey & 3 & $1 \%$ \\
\hline U.A.E. & 5 & $2 \%$ \\
\hline UK & 4 & $1 \%$ \\
\hline Ukraine & 4 & $1 \%$ \\
\hline USA & 26 & $8 \%$ \\
\hline Vietnam & 3 & $1 \%$ \\
\hline
\end{tabular}

\footnotetext{
${ }^{1}$ Of the 27 countries considering or planning for nuclear power in 2012, 10 are from the Asia and the Pacific region, 10 are from the Africa region, 7 are in Europe (mostly Eastern Europe) and 2 are in Latin America. http://www.iaea.org/About/Policy/GC/GC56/GC56InfDocuments/English/gc56inf-6 en.pdf

${ }^{2}$ Countries that might buy a small number of reactors were excluded based on the logic that they are below the economic threshold for fuel manufacturer investment of growth in which nuclear generating capacity is likely to occur.

${ }^{3}$ Italy was removed from consideration as in 2011 the country elected to not pursue development of nuclear energy. Japan was also removed due to the uncertainties tied to recovery from the events at Fukushima.
} 
(a) Based on a nominal 1000 MWe capacity reactor facility.

The countries included in this study were chosen based on nuclear generating capacity projections from the UxC Fabrication Market Outlook 2010 report. That report projected the number of reactor units and total generating capacity for 52 countries that UxC predicts will generate commercial, grid-connected electrical nuclear generating capacity by 2030 .

The projected generating capacity for several countries was limited to the construction of one or two units. These countries were not included in the study, as their probability of building domestic nuclear capacity would overall have a limited impact on the demand of nuclear fuel.

\subsection{Aligning Supply and Demand According to Nuclear Capacity Growth Forecast}

Following identification of a population of anticipated reactor designs and the countries in which the majority of nuclear generating capacity growth is likely to occur, the next step was to align capacity forecast by country with available nuclear technologies by assigning specific reactor types to each country. The country distribution of reactors contains a great deal of information about what general types of reactors will be built, but it does not address specific reactor designs a country may choose (i.e., advanced LWR vs. Westinghouse AP-1000). This approach avoids trying to compare a wide range of designs "on the technological merits" and exploits what many countries have already published about reactors of interest. ${ }^{1}$

The basis of this alignment varied by decade, and greater certainty was associated with reactor technology and vendor design choices in the early years of the study. The UxC nuclear generating capacity projections provided projections of specific reactor types with individual countries through 2030; these projections were used as the basis for the 2012 to 2030 projections. From 2031 to 2050, the rate of nuclear growth in a country for each decade beyond 2030 was determined using a linear projection of pre2030 capacity figures in the UxC data.

\subsection{Net Generation, Retirements, and New Builds}

In order to derive new build forecasts from net capacity forecasts, assumptions on the rate and distribution of retirements for existing reactors were required. To generate a retirements forecast, a set of average reactor lifetimes was assumed based on PNNL expert assessment. Assumed reactor lifetimes are listed in Table 2.2.

Using the projected generating capacity and expected retirements, a required additional nuclear generating capacity was determined for each decade. This capacity represents the amount of new generating capacity a country must bring online within that decade to meet its projected capacity at the end of the decade. The required additional nuclear generating capacity was used as a guide, rather than a rule, while making reactor type/design projections.

\footnotetext{
${ }^{1}$ PNNL analysis in FY 2014 will advance the analysis further by aligning nuclear capacity growth per decade through 2050 by individual country and specific reactor design.
} 
Table 2.2. Reactor Lifetime Assumptions ${ }^{1}$

\begin{tabular}{lc}
\hline \multicolumn{1}{c}{ Reactor Type } & Assumed Lifetime \\
\hline RBMK & 50 \\
Magnox & 50 \\
AGR & 50 \\
Old BWR & 50 \\
New BWR & 60 \\
Old PWR & 60 \\
New PWR & 60 \\
Old VVER & 60 \\
New VVER & 60 \\
PHWR & 60 \\
Fast Breeder Reactor (FBR) & 50 \\
Unknown & 50 \\
\hline
\end{tabular}

To the extent possible, stated nuclear energy development plans for each country were in the projections, as well as documented dates in country profiles available from the World Nuclear Association. ${ }^{2}$ These projections thus take into account explicit design purchases, plans, and proposals that each country has released. In most cases this information was only available for the period from 2021 to 2030. For projections to 2050, common trends identified for reactor types (e.g., LWR, HWR, etc.) were drawn from publicly available information.

See Appendix A for the complete set of country projections.

\footnotetext{
${ }^{1}$ A distinction was made between "new" and "old" reactor types to account for general technical improvement in reactor designs. There is no clear distinction, but "new" reactor types are generally those built in the past 25 years. ${ }^{2} \mathrm{http}: / /$ www.world-nuclear.org/
} 


\subsection{Results}

\subsection{Expert Elicitation to Define Population of Anticipated Reactors}

Using the criteria described in section 2.1, and expert group identified a set of designs as those most likely to be built in our study timeframe. These are primarily advanced LWR designs, specifically, PWRs and BWRs. More advanced versions of PHWRs were judged to be less successful, but still realistic, options for future reactor deployment. Several SMR designs also were considered to be successful, in particular those that are LWR designs. Table 3.1 presents a tabulation of results from the expert elicitation. ${ }^{1}$

Table 3.1. Tabulation of Expert Results ${ }^{2}$

\begin{tabular}{|c|c|c|c|c|c|c|}
\hline Reactor & $\begin{array}{c}\text { Expert } \\
\# 1\end{array}$ & $\begin{array}{c}\text { Expert } \\
\# 2\end{array}$ & $\begin{array}{c}\text { Expert } \\
\# 3\end{array}$ & $\begin{array}{c}\text { Expert } \\
\# 4\end{array}$ & Actual Status & $\begin{array}{l}\text { Proposed Entry } \\
\text { Decade }\end{array}$ \\
\hline $4 \mathrm{~S}$ & never & $12-20$ & $31-40$ & $21-30$ & Conceptual & \\
\hline ABWR & $12-20$ & $12-20$ & $31-40$ & $12-20$ & In operation & $12-20$ \\
\hline ABWR-II & $21-30$ & $31-40$ & $41-50$ & never & Basic Design & $31-40$ \\
\hline ACR-1000 & $12-20$ & $21-30$ & & $12-20$ & Basic design & $21-30$ \\
\hline AHWR & $21-30$ & $50+$ & $50+$ & $31-40$ & Basic design & \\
\hline AP-1000 & $12-20$ & $12-20$ & $31-40$ & $12-20$ & Under construction & $12-20$ \\
\hline AP-600 & never & $41-50$ & $41-50$ & never & Basic Design & \\
\hline APR-1000 & $21-30$ & $31-40$ & $41-50$ & $21-30$ & Basic Design & $21-30$ \\
\hline APR-1400 & $12-20$ & $12-20$ & $31-40$ & $12-20$ & Under Construction & $12-20$ \\
\hline APWR & $12-20$ & $12-20$ & $41-50$ & $12-20$ & $\begin{array}{l}\text { Licensing } \\
\text { certification }\end{array}$ & $12-20$ \\
\hline ATMEA1 & $21-30$ & & $50+$ & $12-20$ & Basic design & \\
\hline CAREM & $12-20$ & & & & Under construction & $12-20$ \\
\hline China HTR-PM & $12-20$ & $50+$ & never & $12-20$ & Under construction & $12-20$ \\
\hline Enhanced CANDU 6 & $21-30$ & never & $50+$ & never & Basic design & \\
\hline EPR & $12-20$ & $12-20$ & $31-40$ & $12-20$ & Under construction & $12-20$ \\
\hline
\end{tabular}

\footnotetext{
${ }^{1}$ Projecting the success of the various reactor designs in various stages of development by its nature draws conflicting opinions, and this was evident among the group of PNNL experts. The PNNL expert group consisted of staff with experience in nuclear reactors (light water, liquid metal, graphite, etc...) and nonproliferation in an effort to establish a rounded base of expertise to reduce potential bias. Regardless of specific background and expertise, the group recognized that global nuclear infrastructure is biased toward supporting light water reactors; therefore, the prevailing opinion favors light water deployment. There was from the start disagreement over what defined a 'viable' reactor concept. Some of the experts believed that a design became viable with the $5^{\text {th }}$ reactor of that design being built; others felt that the design must be accepted globally before it could be considered viable. The projections were made after the April 2011 Fukushima accident, at a time when the impact of the accident on global nuclear energy growth was not clear. The belief that Fukushima would delay the entry of some (in particular Japanese) reactor designs into the market was reflected in the projections of Expert \#3 (thus explaining how a design with a currently operational unit could be assigned a "never" categorization).

2 The 'proposed entry decade' was agreed to as a summary judgment among the four experts. The experts assigned each reactor one of the following projected market entry dates: 1) never; 2) 2012-2020; 3) 2021-2030; 3) 2031-2040; 4) 2041-2050. (The years have been abbreviated in the table - i.e. 12-20 is 2012-2020.)
} 
Table 3.2. Continued

\begin{tabular}{|c|c|c|c|c|c|c|}
\hline Reactor & $\begin{array}{c}\text { Expert } \\
\# 1 \\
\end{array}$ & $\begin{array}{c}\text { Expert } \\
\# 2 \\
\end{array}$ & $\begin{array}{c}\text { Expert } \\
\# 3 \\
\end{array}$ & $\begin{array}{c}\text { Expert } \\
\# 4\end{array}$ & Actual Status & $\begin{array}{c}\text { Proposed Entry } \\
\text { Decade } \\
\end{array}$ \\
\hline ESBWR & $21-30$ & $21-30$ & $41-50$ & $12-20$ & $\begin{array}{l}\text { NRC Final design } \\
\text { approval }\end{array}$ & $21-30$ \\
\hline FBNR & never & never & never & Never & Concept & \\
\hline GA GTMHR & $31-40$ & never & $50+$ & $31-40$ & Detailed design & \\
\hline GTHTR20-300C & never & $41-50$ & $50+$ & never & Conceptual design & \\
\hline HP-LWR & never & never & never & never & Concept description & \\
\hline Hyperion & never & never & $50+$ & $50+$ & Design certification & \\
\hline IMR & never & $50+$ & & $31-40$ & Conceptual design & \\
\hline IPHWR-220 & $12-20$ & $12-20$ & $41-50$ & never & In operation & $12-20$ \\
\hline IPHWR-700 & $12-20$ & $12-20$ & $41-50$ & never & Under construction & $12-20$ \\
\hline IRIS & never & never & never & never & Detailed design & \\
\hline JSCWR & never & $31-40$ & $50+$ & never & Conceptual design & \\
\hline KAMADO-FBR & never & never & never & never & Conceptual design & \\
\hline KERENA & $21-30$ & $50+$ & $41-50$ & $21-30$ & Basic design & $21-30$ \\
\hline KLT-40s & $12-20$ & $12-20$ & $12-20$ & never & Under construction & $12-20$ \\
\hline mPower & $12-20$ & $21-30$ & $41-50$ & $21-30$ & $\begin{array}{c}\text { Preliminary design } \\
\text { review }\end{array}$ & $21-30$ \\
\hline NuScale & $12-20$ & $21-30$ & $41-50$ & $21-30$ & Conceptual design & $12-30$ \\
\hline PRISM & $21-30$ & $21-30$ & never & never & Basic design & \\
\hline RMWR & never & $31-40$ & never & $50+$ & Conceptual design & \\
\hline SMART & $21-30$ & $50+$ & $41-50$ & $21-30$ & Detailed design & $21-30$ \\
\hline South Africa PBMR & never & never & never & never & Project halted & \\
\hline VBER-300 & $21-30$ & $21-30$ & $50+$ & $21-30$ & Conceptual design & $21-30$ \\
\hline VVER 640 (V 407) & $21-30$ & $21-30$ & never & $31-40$ & Basic design & $21-30$ \\
\hline $\begin{array}{l}\text { VVER-1000 (V-466 } \\
\text { B) }\end{array}$ & $12-20$ & $12-20$ & $31-40$ & $12-20$ & Under construction & $12-20$ \\
\hline $\begin{array}{l}\text { VVER-1200 (V- } \\
\text { 392M) }\end{array}$ & $12-20$ & $12-20$ & $31-40$ & $12-20$ & Under construction & $12-20$ \\
\hline VVER-1200 (V-491) & $12-20$ & $12-20$ & $31-40$ & $12-20$ & Under construction & $12-20$ \\
\hline VVER-1500 (V-448) & $21-30$ & $21-30$ & $50+$ & $21-30$ & Detailed design & $21-30$ \\
\hline VVER-300 (V-478) & 21-30 & $12-20$ & never & $12-20$ & Detailed design & 21-30 \\
\hline VVER-600 (V 498) & 21-30 & $21-30$ & never & $31-40$ & Conceptual design & 21-30 \\
\hline
\end{tabular}

Other more radical reactor types, such as molten salt and pebble bed reactors, are under development, and may ultimately be built commercially. Although these reactors may be ready for commercial operation before 2030 , they were not seen to be successful until the latter period of analysis. They are likely to be deployed only after the timeframe considered in this this study. 


\subsection{Conclusions}

The widespread construction of a new set of reactor designs could strain the capacity of existing markets to provide adequate redundancy of supply, since new fuel designs could involve new fabrication technologies, and favor new entrants to the market. For economic reasons, and at least initially, building new reactor designs will rely on single-vendor fuel supply. Fuel supply security is in fact an important factor for states to consider in developing nuclear power. The choices a state makes among various reactor technologies may have implications for fuel supply security; these choices also will impact fuel supply security in the evolving nuclear fuel market.

Since most of the reactors anticipated for deployment in our study timeframe are evolutions of current LWR or PHWR designs, the capabilities of existing vendors are sufficient to fuel the advanced reactors that are starting to be built. It is likely that the incremental improvements in fuel burn-up, giving optimum utilization, will be the main change over the next decade. ${ }^{1}$ The results of this study suggest that there are numerous reactor designs approaching market readiness. Our review of reactor designs in the development stage indicates those that are most mature and likely to be deployed by 2050 are mostly LWR designs with a few PHWR designs. Exceptions, such as gas reactors and fast reactors, are not likely to be market ready prior to 2050. As a result, LWR fuel will continue to dominate the fuel market through the period of analysis. Fuel manufacturing technology for these designs will be an evolutionary adaptation of existing nuclear fuel manufacturing processes, not processes that are fundamentally different from those currently used. As such, it is less likely to be a disruptive factor in the structure and function of fuel markets, and the existing market equilibrium, which tends to offer a high degree of supply security, is likely to be preserved as a new phase of nuclear power growth begins.

Growth of the global nuclear reactor population and the need for nuclear fuel will be driven by three factors: 1) the large scale expansion of nuclear power in China (also India and South Korea); 2) the entry of new nuclear power consumers; and 3) the replacement of existing reactors. Each of these market segments has important implications for the market penetration of new designs. In China, the high number of new builds, the diversity of power markets, and the indigenization of technology and export plans will favor a diversification of technology.

At the same time, new nuclear consumers - those developing nuclear power for the first time-will tend to be risk averse in terms of choosing advanced, less traditional designs. These countries represent a market with no fixed allegiance to designs, as illustrated in the UAE's purchase of four South Korean reactors. ${ }^{2}$ Finally, the replacement of existing reactors will follow the evolution of existing designs and vendors. This market segment will exhibit design-type inertia as consumers follow a pattern of historical allegiance to specific designs and vendors.

\footnotetext{
${ }^{1}$ Current Trends in Nuclear Fuel for Power Reactors. www.iaea.org/About/Policy/GC/GC51/.../gc51inf-3att5_en.pdf.

${ }^{2}$ In December 2009, the UAE and South Korea signed a U.S. \$20 billion contract for construction, commissioning, and fuel loading of four South Korean developed APR-1400 reactors, with another US\$20 billion for operating and maintaining the proposed reactors for a period of 60 years. South Korea's success in the UAE reactor tender solidified its status as a global contender for reactor sales and services, beating out more established Western vendors. The APR-1400 is based on Gen II western technology. Under a licensee relationship with Westinghouse, Korea Hydro and Nuclear Power (updated the Combustion Engineering System 80 design for its own domestic requirements. Korea Hydro and Nuclear Power went on to develop the Korean Standard Nuclear Plant (KNSP), the OPR-1000 design and finally the APR-1400.
} 



\section{Appendix}

PNNL Nuclear Fuel Fabrication Market Model 



\section{Appendix}

\section{PNNL Nuclear Fuel Fabrication Market Model}

Table A.1. Expert Consensus on Reactor Startup Decade

\begin{tabular}{|c|c|c|c|c|}
\hline \multicolumn{5}{|c|}{ Consensus Expert Opinion for Reactor Design Entry into Service } \\
\hline \multicolumn{5}{|c|}{ Large Reactor Designs } \\
\hline \multicolumn{5}{|c|}{ Expected Decade of Entry } \\
\hline $2012-2020$ & $2021-2030$ & 2031-2040 & 2041-2050 & $2050+$ \\
\hline ABWR & ACR-1000 & ABWR-II & & \\
\hline AP-1000 & APR-1000 & & & \\
\hline APR-1400 & ESBWR & & & \\
\hline APWR & KERENA & & & \\
\hline EPR & VBER-300 & & & \\
\hline IPHWR-220 & VVER 640 (V 407) & & & \\
\hline IPHWR-700 & $\begin{array}{l}\text { VVER-1500 (V- } \\
448)\end{array}$ & & & \\
\hline VVER-1000 (V-466 B) & VVER-300 (V-478) & & & \\
\hline VVER-1200 (V-392M) & VVER-600 (V 498) & & & \\
\hline VVER-1200 (V-491) & & & & \\
\hline \multicolumn{5}{|c|}{ Small Reactor Designs } \\
\hline \multicolumn{5}{|c|}{ Expected Decade of Entry } \\
\hline $2012-2020$ & $2021-2030$ & $2031-2040$ & $2041-2050$ & $2050+$ \\
\hline CAREM & mPower & & & \\
\hline China HTR-PM & NuScale & & & \\
\hline KLT-40S & SMART & & & \\
\hline
\end{tabular}

Key: $\operatorname{xxxx}(y) \operatorname{xxxx}=$ expected MWe total $(y)=$ expected number of units

Table A.2. Belarus

\begin{tabular}{|l|r|r|r|r|}
\hline \multicolumn{1}{|c|}{ Unit } & \multicolumn{3}{c|}{ Decade } \\
\hline \multicolumn{1}{|c|}{ Gen III/III+ PWR (1000 MWe) } & $2012-20$ & $2021-30$ & $2031-40$ & $2041-50$ \\
\hline LWR SMR & $1200(1)$ & $1200(1)$ & & $1200(1)$ \\
\hline & & & & $(1)$ \\
\hline Capacity at Beginning of Decade & & & & \\
\hline Decline in 2012 Capacity over Decade (Shutdowns) & 0 & 1000 & 2000 & 3000 \\
\hline Capacity at Beginning of Decade Less Shutdown Losses & 0 & 0 & 0 & 0 \\
\hline UxC Projected Capacity at End of Decade & 0 & 1000 & 2000 & 3000 \\
\hline Required Additional Capacity & 1000 & 2000 & 3000 & 4000 \\
\hline
\end{tabular}


Table A.3. Brazil

\begin{tabular}{|c|c|c|c|c|}
\hline & \multicolumn{4}{|c|}{ Decade } \\
\hline Unit & $2012-20$ & $2021-30$ & $2031-40$ & $2041-50$ \\
\hline Gen III/III+ PWR (1000 MWe) & $\begin{array}{c}1350 \\
(1)\end{array}$ & $\begin{array}{c}4000 \\
(4)\end{array}$ & $2000(2)$ & $\begin{array}{c}4000 \\
(4)\end{array}$ \\
\hline LWR SMR & & & $(1-2)$ & $(1-2)$ \\
\hline $\begin{array}{c}\text { Non-LWR SMR } \\
\text { Potential for domestic pebble fuel (FBNR) } \\
\text { Small CANDU }\end{array}$ & & (1) & & \\
\hline Capacity at Beginning of Decade & 1884 & 3125 & 7475 & 11825 \\
\hline Decline in 2012 Capacity over Decade (Shutdowns) & 0 & 0 & 0 & -609 \\
\hline Capacity at Beginning of Decade Less Shutdown Losses & 1884 & 3125 & 7475 & 11216 \\
\hline UxC Projected Capacity at End of Decade & 3125 & 7475 & 11825 & 16175 \\
\hline Required Additional Capacity & 1241 & 4350 & 4350 & 4959 \\
\hline
\end{tabular}

Table A.4. Bulgaria

\begin{tabular}{|c|c|c|c|c|}
\hline & \multicolumn{4}{|c|}{ Decade } \\
\hline Unit & 2012-20 & 2021-30 & $2031-40$ & $2041-50$ \\
\hline Gen III/III+ PWR (1000 MWe) & & $\begin{array}{c}3000(2- \\
3)\end{array}$ & $2000(2)$ & $\begin{array}{l}3000 \\
(3)\end{array}$ \\
\hline LWR SMR & & & (1) & (4) \\
\hline Non-LWR SMR & & & $(1)$ & $(2)$ \\
\hline Capacity at Beginning of Decade & 1906 & 2917 & 5928 & 8939 \\
\hline Decline in 2012 Capacity over Decade (Shutdowns) & 0 & 0 & 0 & 0 \\
\hline Capacity at Beginning of Decade Less Shutdown Losses & 1906 & 2917 & 5928 & 8939 \\
\hline UxC Projected Capacity at End of Decade & 2917 & 5928 & 8939 & 11950 \\
\hline Required Additional Capacity & 1011 & 3011 & 3011 & 3011 \\
\hline
\end{tabular}

Table A.5. Canada

\begin{tabular}{|c|c|c|c|c|}
\hline & \multicolumn{4}{|c|}{ Decade } \\
\hline Unit & 2012-20 & 2021-30 & $2031-40$ & $2041-50$ \\
\hline Advanced HWR (1200 MWe) & & $\begin{array}{c}2400 \\
(2)\end{array}$ & $2400(2)$ & $\begin{array}{c}2400 \\
(2)\end{array}$ \\
\hline $\begin{array}{c}\text { LWR SMR } \\
\text { Something for outposts }\end{array}$ & & & (1) & (1) \\
\hline $\begin{array}{c}\text { Non-LWR SMR } \\
\text { Small CANDUs (EC-6) } \\
\text { Little potential for Small LMFBR like 4S for outpost }\end{array}$ & $\begin{array}{l}1200 \\
(2)\end{array}$ & & & \\
\hline Capacity at Beginning of Decade & 14179 & 15237 & 17860 & 20483 \\
\hline Decline in 2012 Capacity over Decade (Shutdowns) & 0 & 0 & 0 & 0 \\
\hline Capacity at Beginning of Decade Less Shutdown Losses & 14179 & 15237 & 17860 & 20483 \\
\hline UxC Projected Capacity at End of Decade & 15237 & 17860 & 20483 & 23106 \\
\hline Required Additional Capacity & 1058 & 2623 & 2623 & 2623 \\
\hline
\end{tabular}


Table A.6. China

\begin{tabular}{|c|c|c|c|c|}
\hline & \multicolumn{4}{|c|}{ Decade } \\
\hline Unit & $2012-20$ & $2021-30$ & $2031-40$ & $2041-50$ \\
\hline Gen II/III PWR (1000 MWe) & $\begin{array}{c}34,000 \\
(34)\end{array}$ & $16,000(16)$ & $30,000(30)$ & $\begin{array}{c}10,000 \\
(10)\end{array}$ \\
\hline Gen III+ PWR (1500 MWe) & $\begin{array}{c}27,000 \\
(18) \\
\end{array}$ & $45,000(30)$ & $22,500(15)$ & $\begin{array}{c}45,000 \\
(30)\end{array}$ \\
\hline Advanced BWR (1000 MWe) & & & $5,000(5)$ & $\begin{array}{c}10,000 \\
(10)\end{array}$ \\
\hline Advanced HWR (1000 MWe) & & $2,400(2)$ & $4000(4-5)$ & $\begin{array}{l}4000(4- \\
5)\end{array}$ \\
\hline Gen IV & $\begin{array}{c}1,760 \\
(2)\end{array}$ & $1,760(2)$ & (1) & (2) \\
\hline LWR SMR & $(2)$ & $(10)$ & $(5-10)$ & \\
\hline $\begin{array}{c}\text { Non-LWR SMR } \\
\text { Everything (pebble, LMFR, etc) }\end{array}$ & (1) & $(4-8)$ & $(2-4)$ & \\
\hline Capacity at Beginning of Decade & 11816 & 70216 & 133216 & 196216 \\
\hline Decline in 2012 Capacity over Decade (Shutdowns) & 0 & 0 & -298 & -1888 \\
\hline Capacity at Beginning of Decade Less Shutdown Losses & 11816 & 70216 & 132918 & 194328 \\
\hline UxC Projected Capacity at End of Decade & 70216 & 133216 & 196216 & 259216 \\
\hline Required Additional Capacity & 58400 & 63000 & 63298 & 64888 \\
\hline
\end{tabular}

Table A.7. Czech Republic

\begin{tabular}{|l|r|r|r|r|}
\hline \multicolumn{1}{|c|}{ Unit } & \multicolumn{5}{c|}{ Decade } \\
\hline Gen III LWR (1000 MWe) & $2012-20$ & $2021-30$ & $2031-40$ & $2041-50$ \\
\hline LWR SMR & & $\begin{array}{c}2000 \\
(2)\end{array}$ & $2000(2)$ & $2000(2)$ \\
\hline Non-LWR SMR & & & & \\
\hline & & & & \\
\hline Capacity at Beginning of Decade & & & & \\
\hline Decline in 2012 Capacity over Decade (Shutdowns) & 0 & 3703 & 5703 & 7703 \\
\hline Capacity at Beginning of Decade Less Shutdown Losses & 0 & 0 & 0 & 0 \\
\hline UxC Projected Capacity at End of Decade & 3703 & 5703 & 5703 & 7703 \\
\hline Required Additional Capacity & 3703 & 2000 & 7703 & 9703 \\
\hline
\end{tabular}


Table A.8. Egypt

\begin{tabular}{|l|r|r|r|r|}
\hline \multicolumn{1}{|c|}{ Unit } & \multicolumn{3}{c|}{ Decade } \\
\hline Gen III LWR (1000 MWe) & $2012-20$ & $2021-30$ & $2031-40$ & $2041-50$ \\
\hline LWR SMR & & $\begin{array}{c}1000 \\
(1)\end{array}$ & $1000(1)$ & $2000(2)$ \\
\hline Non-LWR SMR & & & & \\
\hline & & & & \\
\hline Capacity at Beginning of Decade & & & & \\
\hline Decline in 2012 Capacity over Decade (Shutdowns) & 0 & 1000 & 2000 & 3000 \\
\hline Capacity at Beginning of Decade Less Shutdown Losses & 0 & 0 & 0 & 0 \\
\hline UxC Projected Capacity at End of Decade & 0 & 1000 & 2000 & 3000 \\
\hline Required Additional Capacity & 1000 & 2000 & 3000 & 4000 \\
\hline
\end{tabular}

Table A.9. Finland

\begin{tabular}{|c|c|c|c|c|}
\hline & \multicolumn{4}{|c|}{ Decade } \\
\hline Unit & $2012-20$ & $2021-30$ & $2031-40$ & 2041-50 \\
\hline Gen III/III+ LWR (1500 MWe) & $\begin{array}{c}3000 \\
(2)\end{array}$ & $3000(2)$ & $3000(2)$ & $\begin{array}{c}3000 \\
(2)\end{array}$ \\
\hline \multicolumn{5}{|l|}{ LWR SMR } \\
\hline \multicolumn{5}{|l|}{ Non-LWR SMR } \\
\hline Capacity at Beginning of Decade & 2752 & 5896 & 7496 & 9096 \\
\hline Decline in 2012 Capacity over Decade (Shutdowns) & 0 & -1760 & -992 & 0 \\
\hline Capacity at Beginning of Decade Less Shutdown Losses & 2752 & 4136 & 6504 & 9096 \\
\hline UxC Projected Capacity at End of Decade & 5896 & 7496 & 9096 & 10696 \\
\hline Required Additional Capacity & 3144 & 3360 & 2592 & 1600 \\
\hline
\end{tabular}

Table A.10. France

\begin{tabular}{|c|c|c|c|c|}
\hline & \multicolumn{4}{|c|}{ Decade } \\
\hline Unit & $2012-20$ & $2021-30$ & $2031-40$ & $2041-50$ \\
\hline Gen III/III+ LWR (1500 MWe) & $4500(3)$ & $7500(5)$ & $15,000(10)$ & $22,500(15)$ \\
\hline LWR SMR & & & $(2)$ & \\
\hline $\begin{array}{c}\text { Non-LWR SMR } \\
\text { LMFR }\end{array}$ & & & $(2)$ & \\
\hline Gen IV & & & $(1)$ & $(1-2)$ \\
\hline & & & & \\
\hline Capacity at Beginning of Decade & 63130 & 68140 & 76480 & 84820 \\
\hline Decline in 2012 Capacity over Decade (Shutdowns) & 0 & 0 & -11680 & -19090 \\
\hline Capacity at Beginning of Decade Less Shutdown Losses & 63130 & 68140 & 64800 & 65730 \\
\hline UxC Projected Capacity at End of Decade & 68140 & 76480 & 84820 & 93160 \\
\hline Required Additional Capacity & 5010 & 8340 & 20020 & 27430 \\
\hline
\end{tabular}


Table A.11. Hungary

\begin{tabular}{|c|c|c|c|c|}
\hline & \multicolumn{4}{|c|}{ Decade } \\
\hline Unit & 2012-20 & 2021-30 & $2031-40$ & $2041-50$ \\
\hline Gen III/III+ LWR (1000 MWe) & & $\begin{array}{c}2000 \\
(2)\end{array}$ & $2000(2)$ & $2000(2)$ \\
\hline Non-LWR SMR & & & $(1)$ & \\
\hline Capacity at Beginning of Decade & 0 & 1886 & 4336 & 6786 \\
\hline Decline in 2012 Capacity over Decade (Shutdowns) & 0 & 0 & 0 & 0 \\
\hline Capacity at Beginning of Decade Less Shutdown Losses & 0 & 1886 & 4336 & 6786 \\
\hline UxC Projected Capacity at End of Decade & 1886 & 4336 & 6786 & 9236 \\
\hline Required Additional Capacity & 1886 & 2450 & 2450 & 2450 \\
\hline
\end{tabular}

Table A.12. India

\begin{tabular}{|c|c|c|c|c|}
\hline \multicolumn{1}{|c|}{ Unit } & \multicolumn{4}{c|}{ Decade } \\
\hline Domestic HWR (700 MWe) & $2012-20$ & $2021-30$ & \multicolumn{1}{c|}{$2031-40$} & $2041-50$ \\
\hline Gen III/III+ LWR (1000 MWe) & $4900(7)$ & $5600(8)$ & $7000(10)$ & $6000(8-9)$ \\
\hline Gen IV (1000 MWe) & $8000(8)$ & $\begin{array}{c}10,000 \\
(10)\end{array}$ & $\begin{array}{c}10,000 \\
(10)\end{array}$ & $10,000(10)$ \\
\hline $\begin{array}{c}\text { Non-LWR SMR } \\
\text { LMFRs }\end{array}$ & $1000(1)$ & $2000(2)$ & $5000(5)$ & $7000(5-7)$ \\
\hline & $(1)$ & $(4)$ & $(7-9)$ & \\
\hline Capacity at Beginning of Decade & & & & \\
\hline Decline in 2012 Capacity over Decade (Shutdowns) & -300 & -90 & -799 & -1414 \\
\hline Capacity at Beginning of Decade Less Shutdown Losses & 4091 & 18272 & 34987 & 51796 \\
\hline UxC Projected Capacity at End of Decade & 18362 & 35786 & 53210 & 70634 \\
\hline Required Additional Capacity & 14271 & 17514 & 18223 & 18838 \\
\hline
\end{tabular}

Table A.13. Mexico

\begin{tabular}{|l|r|r|r|r|}
\hline \multicolumn{1}{|c|}{ Unit } & \multicolumn{3}{c|}{ Decade } \\
\hline \multicolumn{1}{|c|}{ Gen III/III+ LWR (1000 MWe) } & $2012-20$ & $2021-30$ & $2031-40$ & $2041-50$ \\
\hline & & $2000(2)$ & $2000(2)$ & $\begin{array}{c}3000 \\
(3)\end{array}$ \\
\hline & & & & \\
\hline Capacity at Beginning of Decade & & & & \\
\hline Decline in 2012 Capacity over Decade (Shutdowns) & 0 & 1598 & 4248 & 6898 \\
\hline Capacity at Beginning of Decade Less Shutdown Losses & 0 & 0 & 0 & 0 \\
\hline UxC Projected Capacity at End of Decade & 0 & 1598 & 4248 & 6898 \\
\hline Required Additional Capacity & 1598 & 4248 & 6898 & 9548 \\
\hline
\end{tabular}


Table A.14. Poland

\begin{tabular}{|l|r|r|r|r|}
\hline \multicolumn{1}{|c|}{ Unit } & \multicolumn{5}{c|}{ Decade } \\
\hline \multicolumn{1}{|c|}{ Gen III/III+ LWR (1000 MWe) } & $2012-20$ & $2021-30$ & $2031-40$ & \multicolumn{1}{c|}{$2041-50$} \\
\hline LWR SMR & & $\begin{array}{c}2000 \\
(2)\end{array}$ & $3000(3)$ & $\begin{array}{c}3000 \\
(3)\end{array}$ \\
\hline Non-LWR SMR & & & & \\
\hline & & & & \\
\hline Capacity at Beginning of Decade & & & & \\
\hline Decline in 2012 Capacity over Decade (Shutdowns) & 0 & 0 & 3200 & 6400 \\
\hline Capacity at Beginning of Decade Less Shutdown Losses & 0 & 0 & 0 & 0 \\
\hline UxC Projected Capacity at End of Decade & 0 & 3200 & 6400 & 9600 \\
\hline Required Additional Capacity & 0 & 3200 & 3200 & 3200 \\
\hline
\end{tabular}

Table A.15. Russia

\begin{tabular}{|c|c|c|c|r|}
\hline & \multicolumn{3}{c|}{ Decade } \\
\hline \multicolumn{1}{|c|}{ Unit } & $2012-20$ & $2021-30$ & $2031-40$ & $2041-50$ \\
\hline Gen III/III+ PWR (1000-1500 MWe) & $\begin{array}{c}8500 \\
(7)\end{array}$ & $14,000(11)$ & $15,000(15)$ & $5000(5)$ \\
\hline Gen IV & $800(1)$ & $2400(2)$ & $2400(2)$ & $2400(2)$ \\
\hline LWR SMR & $(3)$ & $(2-4)$ & $(5-7)$ & $(10)$ \\
\hline Non-LWR SMR & $(1)$ & $(1-2)$ & $(2-3)$ & \\
\hline Capacity at Beginning of Decade & & & & \\
\hline Decline in 2012 Capacity over Decade (Shutdowns) & 23643 & 32854 & 40933 & 49012 \\
\hline Capacity at Beginning of Decade Less Shutdown Losses & 0 & -7771 & -11122 & -950 \\
\hline UxC Projected Capacity at End of Decade & 23643 & 25083 & 29811 & 48062 \\
\hline Required Additional Capacity & 32854 & 40933 & 49012 & 57091 \\
\hline
\end{tabular}

Table A.16. Spain

\begin{tabular}{|l|r|r|r|r|}
\hline \multicolumn{1}{|c|}{ Unit } & \multicolumn{4}{c|}{ Decade } \\
\hline \multicolumn{1}{|c|}{ Gen III/III+ LWR (1500 MWe) } & $2012-20$ & $2021-30$ & \multicolumn{1}{c|}{$2031-40$} & \multicolumn{1}{c|}{$2041-50$} \\
\hline LWR SMR & & $\begin{array}{c}3000 \\
(2)\end{array}$ & $4500(3)$ & $6000(4)$ \\
\hline Non-LWR SMR & & & & \\
\hline & & & & \\
\hline Capacity at Beginning of Decade & & & & \\
\hline Decline in 2012 Capacity over Decade (Shutdowns) & 7560 & 7560 & 9454 & 11904 \\
\hline Capacity at Beginning of Decade Less Shutdown Losses & 0 & -446 & 0 & -5050 \\
\hline UxC Projected Capacity at End of Decade & 7560 & 7114 & 9454 & 6854 \\
\hline Required Additional Capacity & 7560 & 9454 & 11904 & 14354 \\
\hline
\end{tabular}


Table A.17. South Africa

\begin{tabular}{|l|r|r|r|r|}
\hline \multicolumn{1}{|c|}{ Unit } & \multicolumn{4}{c|}{ Decade } \\
\hline Gen III/III+ LWR (1000 MWe) & $2012-20$ & $2021-30$ & $2031-40$ & $2041-50$ \\
\hline LWR SMR & & $2000(2)$ & $2000(2)$ & $4000(4)$ \\
\hline Non-LWR SMR & & & & \\
\hline & & & & \\
\hline Capacity at Beginning of Decade & & & & \\
\hline Decline in 2012 Capacity over Decade (Shutdowns) & 1830 & 3400 & 6300 & 9200 \\
\hline Capacity at Beginning of Decade Less Shutdown Losses & 1830 & 3400 & 6300 & 7370 \\
\hline UxC Projected Capacity at End of Decade & 3400 & 6300 & 9200 & 12100 \\
\hline Required Additional Capacity & 1570 & 2900 & 2900 & 4730 \\
\hline
\end{tabular}

Table A.18. South Korea

\begin{tabular}{|c|r|r|r|r|}
\hline \multicolumn{1}{|c|}{ Unit } & \multicolumn{4}{c|}{ Decade } \\
\hline Gen II LWR (1000 MWe) & $2012-20$ & $2021-30$ & $2031-40$ & $2041-50$ \\
\hline Gen III/III+ LWR (1500 MWe) & $\begin{array}{c}1000 \\
(1)\end{array}$ & $\begin{array}{c}2000 \\
(2)\end{array}$ & & \\
\hline LWR SMR & $\begin{array}{c}6000 \\
(4)\end{array}$ & $\begin{array}{c}6000 \\
(4)\end{array}$ & $7500(5)$ & $\begin{array}{c}7500 \\
(5)\end{array}$ \\
\hline Non-LWR SMR & $(1)$ & & $(1)$ & \\
\hline Gen IV & & & & \\
\hline & & & & $(1)$ \\
\hline & & & & \\
\hline Capacity at Beginning of Decade & 20671 & 29380 & 38187 & 46994 \\
\hline Decline in 2012 Capacity over Decade (Shutdowns) & 0 & 0 & -576 & 0 \\
\hline Capacity at Beginning of Decade Less Shutdown Losses & 20671 & 29380 & 37611 & 46994 \\
\hline UxC Projected Capacity at End of Decade & 29380 & 38187 & 46994 & 55801 \\
\hline Required Additional Capacity & 8709 & 8807 & 9383 & 8807 \\
\hline
\end{tabular}

Table A.19. Taiwan

\begin{tabular}{|l|r|r|r|r|}
\hline \multicolumn{1}{|c|}{ Unit } & \multicolumn{3}{c|}{ Decade } \\
\hline \multicolumn{1}{|c|}{ Gen III/III+ LWR (1500 MWe) } & $2012-20$ & $2021-30$ & $2031-40$ & $2041-50$ \\
\hline LWR SMR & $\begin{array}{c}3000 \\
(2)\end{array}$ & $\begin{array}{c}3000 \\
(2)\end{array}$ & $3000(2)$ & $3000(2)$ \\
\hline Non-LWR SMR & & & & \\
\hline & & & & \\
\hline Capacity at Beginning of Decade & 5018 & 7484 & 10326 & 13168 \\
\hline Decline in 2012 Capacity over Decade (Shutdowns) & 0 & -1208 & 0 & -1840 \\
\hline Capacity at Beginning of Decade Less Shutdown Losses & 5018 & 6276 & 10326 & 11328 \\
\hline UxC Projected Capacity at End of Decade & 7484 & 10326 & 13168 & 16010 \\
\hline Required Additional Capacity & 2466 & 4050 & 2842 & 4682 \\
\hline
\end{tabular}


Table A.20. Thailand

\begin{tabular}{|c|r|r|r|r|}
\hline \multicolumn{1}{|c|}{ Unit } & \multicolumn{4}{c|}{ Decade } \\
\hline \multicolumn{1}{|c|}{ Gen III LWR (1000 MWe) } & $2012-20$ & $2021-30$ & $2031-40$ & $2041-50$ \\
\hline LWR SMR & & $\begin{array}{c}2000 \\
(2)\end{array}$ & $1000(1)$ & $1000(1)$ \\
\hline $\begin{array}{c}\text { Non-LWR SMR } \\
\text { Pebble }\end{array}$ & & $(1)$ & $(2-4)$ & \\
\hline & & & $(1)$ & \\
\hline Capacity at Beginning of Decade & 0 & 0 & 2000 & 4000 \\
\hline Decline in 2012 Capacity over Decade (Shutdowns) & 0 & 0 & 0 & 0 \\
\hline Capacity at Beginning of Decade Less Shutdown Losses & 0 & 0 & 2000 & 4000 \\
\hline UxC Projected Capacity at End of Decade & 0 & 2000 & 4000 & 6000 \\
\hline Required Additional Capacity & 0 & 2000 & 2000 & 2000 \\
\hline
\end{tabular}

Table A.21. Turkey

\begin{tabular}{|l|r|r|r|r|}
\hline \multicolumn{1}{|c|}{ Unit } & \multicolumn{4}{c|}{ Decade } \\
\hline \multicolumn{1}{|c|}{ Gen III/III+ LWR (1500 MWe) } & $2012-20$ & $2021-30$ & \multicolumn{1}{c|}{$2031-40$} & $2041-50$ \\
\hline LWR SMR & $\begin{array}{c}1500 \\
(1)\end{array}$ & $\begin{array}{c}4500 \\
(3)\end{array}$ & $6000(4)$ & $1500(1)$ \\
\hline Non-LWR SMR & & & & \\
\hline & & & & \\
\hline Capacity at Beginning of Decade & 0 & 1000 & 3000 & 5000 \\
\hline Decline in 2012 Capacity over Decade (Shutdowns) & 0 & 0 & 0 & 0 \\
\hline Capacity at Beginning of Decade Less Shutdown Losses & 0 & 1000 & 3000 & 5000 \\
\hline UxC Projected Capacity at End of Decade & 1000 & 3000 & 5000 & 7000 \\
\hline Required Additional Capacity & 1000 & 2000 & 2000 & 2000 \\
\hline
\end{tabular}

Table A.22. United Arab Emirates

\begin{tabular}{|c|c|c|c|c|}
\hline \multirow[b]{2}{*}{ Unit } & \multicolumn{4}{|c|}{ Decade } \\
\hline & $2012-20$ & $2021-30$ & 2031-40 & $2041-50$ \\
\hline Gen III/III+ LWR (1500 MWe) & $\begin{array}{c}5500 \\
(4)\end{array}$ & & $3000(2)$ & \\
\hline \multicolumn{5}{|l|}{ LWR SMR } \\
\hline \multicolumn{5}{|l|}{ Non-LWR SMR } \\
\hline Capacity at Beginning of Decade & 0 & 5360 & 5360 & 5360 \\
\hline Decline in 2012 Capacity over Decade (Shutdowns) & 0 & 0 & 0 & 0 \\
\hline Capacity at Beginning of Decade Less Shutdown Losses & 0 & 5360 & 5360 & 5360 \\
\hline UxC Projected Capacity at End of Decade & 5360 & 5360 & 5360 & 5360 \\
\hline Required Additional Capacity & 5360 & 0 & 0 & 0 \\
\hline
\end{tabular}


Table A.23. United Kingdom

\begin{tabular}{|c|c|c|c|c|}
\hline \multirow[b]{2}{*}{ Unit } & \multicolumn{4}{|c|}{ Decade } \\
\hline & 2012-20 & 2021-30 & $2031-40$ & $2041-50$ \\
\hline Gen III/III+ LWR (1500 MWe) & $\begin{array}{l}3000 \\
(2)\end{array}$ & $4500(3)$ & $7500(5)$ & $3000(3)$ \\
\hline \multicolumn{5}{|l|}{ LWR SMR } \\
\hline \multicolumn{5}{|l|}{ Non-LWR SMR } \\
\hline Capacity at Beginning of Decade & 9243 & 12116 & 14656 & 17196 \\
\hline Decline in 2012 Capacity over Decade (Shutdowns) & 0 & -2220 & -5835 & 0 \\
\hline Capacity at Beginning of Decade Less Shutdown Losses & 9243 & 9896 & 8821 & 17196 \\
\hline UxC Projected Capacity at End of Decade & 12116 & 14656 & 17196 & 19736 \\
\hline Required Additional Capacity & 2873 & 4760 & 8375 & 2540 \\
\hline
\end{tabular}

Table A.24. Ukraine

\begin{tabular}{|c|c|c|c|c|}
\hline \multirow[b]{2}{*}{ Unit } & \multicolumn{4}{|c|}{ Decade } \\
\hline & $2012-20$ & $2021-30$ & $2031-40$ & $2041-50$ \\
\hline Gen III/III+ LWR (1000 MWe) & $\begin{array}{c}2000 \\
(2)\end{array}$ & $2000(2)$ & $1500(1)$ & $3000(2)$ \\
\hline LWR SMR & & & $(1)$ & \\
\hline Non-LWR SMR & & & $(1)$ & \\
\hline Capacity at Beginning of Decade & 13107 & 15095 & 17535 & 19975 \\
\hline Decline in 2012 Capacity over Decade (Shutdowns) & 0 & 0 & -381 & -376 \\
\hline Capacity at Beginning of Decade Less Shutdown Losses & 13107 & 15095 & 17154 & 19599 \\
\hline UxC Projected Capacity at End of Decade & 15095 & 17535 & 19975 & 22415 \\
\hline Required Additional Capacity & 1988 & 2440 & 2821 & 2816 \\
\hline
\end{tabular}

Table A.25. United States of America

\begin{tabular}{|l|r|r|r|r|}
\hline \multicolumn{1}{|c|}{ Unit } & \multicolumn{4}{c|}{ Decade } \\
\hline Gen III/III+ LWR (1500 MWe) & $2012-20$ & $2021-30$ & $2031-40$ & \multicolumn{1}{c|}{$2041-50$} \\
\hline Gen IV & $15,000(10)$ & $20,000(20)$ & $\begin{array}{c}22,500 \\
(15)\end{array}$ & \multicolumn{1}{c|}{$\begin{array}{c}37,500 \\
(25)\end{array}$} \\
\hline LWR SMR & & & $(1)$ & $(1)$ \\
\hline Non-LWR SMR & & $(3-4)$ & $(2-4)$ & \\
\hline & & & $(1)$ & \\
\hline Capacity at Beginning of Decade & & & & \\
\hline Decline in 2012 Capacity over Decade (Shutdowns) & 101409 & 111425 & 126567 & 141709 \\
\hline Capacity at Beginning of Decade Less Shutdown Losses & -2102 & -17727 & -27538 & -4450 \\
\hline UxC Projected Capacity at End of Decade & 99307 & 93698 & 99029 & 137259 \\
\hline Required Additional Capacity & 111425 & 126567 & 141709 & 156851 \\
\hline
\end{tabular}


Table A.26. Vietnam

\begin{tabular}{|c|r|r|r|r|}
\hline & \multicolumn{4}{|c|}{ Decade } \\
\hline Unit & $2012-20$ & $2021-30$ & $2031-40$ & $2041-50$ \\
\hline Gen III/III+ LWR (1000 MWe) & $\begin{array}{c}1000 \\
(1)\end{array}$ & $2000(2)$ & $2000(2)$ & $2000(2)$ \\
\hline LWR SMR & & & $(1)$ & \\
\hline $\begin{array}{c}\text { Non-LWR SMR } \\
\text { Pebble }\end{array}$ & & & \multicolumn{1}{c|}{$(1)$} & \\
\hline & & & & \\
\hline Capacity at Beginning of Decade & 0 & 1000 & 3000 & 5000 \\
\hline Decline in 2012 Capacity over Decade (Shutdowns) & 0 & 0 & 0 & 0 \\
\hline Capacity at Beginning of Decade Less Shutdown Losses & 0 & 1000 & 3000 & 5000 \\
\hline UxC Projected Capacity at End of Decade & 1000 & 3000 & 5000 & 7000 \\
\hline Required Additional Capacity & 1000 & 2000 & 2000 & 2000 \\
\hline
\end{tabular}

\section{Sensitivities}

Table A.27. India

\begin{tabular}{|c|c|c|c|c|}
\hline \multirow[b]{2}{*}{ Unit } & \multicolumn{4}{|c|}{ Decade } \\
\hline & $2012-20$ & 2021-30 & $2031-40$ & $2041-50$ \\
\hline Domestic HWR (700 MWe) & (4) & $(3-4)$ & $(3-4)$ & $(8-9)$ \\
\hline Gen III/III+ LWR (1000 MWe) & (2) & $(2-4)$ & $(4-6)$ & $(4-6)$ \\
\hline Gen IV (1000 MWe) & & & & \\
\hline $\begin{array}{l}\text { Non-LWR SMR } \\
\text { LMFRs }\end{array}$ & (1) & $(1-2)$ & $(2-3)$ & $(2-3)$ \\
\hline Capacity at Beginning of Decade & 4391 & 18362 & 35786 & 53210 \\
\hline Decline in 2012 Capacity over Decade (Shutdowns) & -300 & -90 & -799 & -1414 \\
\hline Capacity at Beginning of Decade Less Shutdown Losses & 4091 & 18272 & 34987 & 51796 \\
\hline UxC Projected Capacity at End of Decade & 18362 & 35786 & 53210 & 70634 \\
\hline Required Additional Capacity & 14271 & 17514 & 18223 & 18838 \\
\hline
\end{tabular}


Table A.28. China

\begin{tabular}{|c|c|c|c|c|}
\hline & \multicolumn{4}{|c|}{ Decade } \\
\hline Unit & $2012-20$ & $2021-30$ & $2031-40$ & $2041-50$ \\
\hline Gen II/III PWR (1000 MWe) & $\begin{array}{c}34,000 \\
(34)\end{array}$ & $16,000(16)$ & $(10)$ & $(10-15)$ \\
\hline Gen III+ PWR (1500 MWe) & $\begin{array}{c}27,000 \\
(18)\end{array}$ & $45,000(30)$ & $(10)$ & $(10-15)$ \\
\hline Advanced BWR (1000 MWe) & & & $(5)$ & $(10)$ \\
\hline Advanced HWR (1000 MWe) & & $2,400(2)$ & $4000(4-5)$ & $\begin{array}{c}4000(4- \\
5)\end{array}$ \\
\hline Gen IV & $\begin{array}{c}1,760 \\
(2)\end{array}$ & $1,760(2)$ & $(1)$ & $(2)$ \\
\hline LWR SMR & $(2)$ & $(10)$ & $(5-10)$ & \\
\hline Non-LWR SMR & $(1)$ & $(4-8)$ & $(2-4)$ & \\
\hline Everything (pebble, LMFR, etc) & & & & \\
\hline & 11816 & 70216 & 133216 & 196216 \\
\hline Capacity at Beginning of Decade & 0 & & -298 & -1888 \\
\hline Decline in 2012 Capacity over Decade (Shutdowns) & 11816 & 70216 & 132918 & 194328 \\
\hline Capacity at Beginning of Decade Less Shutdown Losses & 70216 & 133216 & 196216 & 259216 \\
\hline UxC Projected Capacity at End of Decade & 58400 & 63000 & 63298 & 64888 \\
\hline Required Additional Capacity & &
\end{tabular}

Table A.29. Russia

\begin{tabular}{|l|r|r|r|r|}
\hline & \multicolumn{3}{c|}{ Decade } \\
\hline Unit & \multicolumn{1}{|c|}{$2012-20$} & $2021-30$ & $2031-40$ & \multicolumn{1}{c|}{$2041-50$} \\
\hline Gen III/III+ PWR (1000-1500 MWe) & $\begin{array}{c}8500 \\
(7)\end{array}$ & $(5-7)$ & $(5-7)$ & \multicolumn{1}{c|}{$(5-7)$} \\
\hline Gen IV & $800(1)$ & $2400(2)$ & $2400(2)$ & $2400(2)$ \\
\hline LWR SMR & $(3)$ & $(2-4)$ & $(2-3)$ & $(2-3)$ \\
\hline Non-LWR SMR & $(1)$ & $(1-2)$ & $(2-3)$ & \\
\hline & & & & \\
\hline Capacity at Beginning of Decade & 23643 & 32854 & 40933 & 49012 \\
\hline Decline in 2012 Capacity over Decade (Shutdowns) & 0 & -7771 & -11122 & -950 \\
\hline Capacity at Beginning of Decade Less Shutdown Losses & 23643 & 25083 & 29811 & 48062 \\
\hline UxC Projected Capacity at End of Decade & 32854 & 40933 & 49012 & 57091 \\
\hline Required Additional Capacity & 9211 & 15850 & 19201 & 9029 \\
\hline
\end{tabular}





\section{Distribution}

No. of

Copies

\# Name

Organization

Address

City, State and ZIP Code

\# Organization

Address

City, State and ZIP Code

Name

Name

Name

Name

Name (\#)

\# Name

Organization

Address

City, State and ZIP Code
No. of

$\underline{\text { Copies }}$

\# Foreign Distribution

\# Name

Organization

Address

Address line 2

COUNTRY

\# Local Distribution

Pacific Northwest National Laboratory

Name

Name

Name

Name

Name
Mailstop

Mailstop

Mailstop

Mailstop

(PDF)

Distr.1 




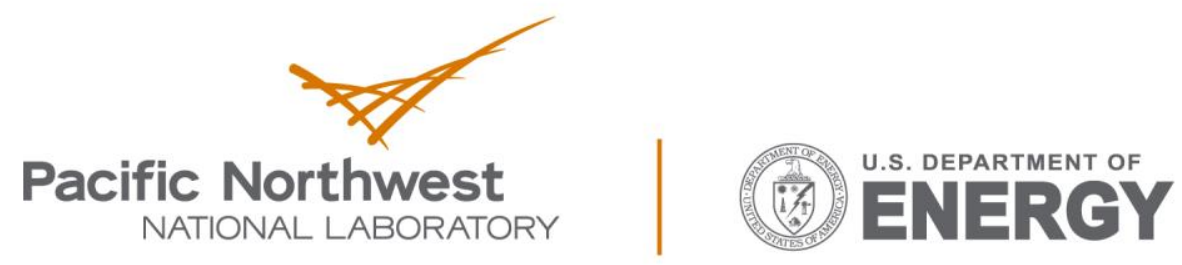

Proudly Operated by Battelle Since 1965

902 Battelle Boulevard

P.O. Box 999

Richland, WA 99352

1-888-375-PNNL (7665)

www.pnnl.gov 